\title{
ECONOMIC ANNALYSIS OF TRADITIONAL AND SRI METHOD OF PADDY CULTIVATION
}

\author{
N. V. Shende ${ }^{1 *}$, P. V. Shende ${ }^{2}$ and R. S. Thorat ${ }^{3}$ \\ *l Associate Professor, Agricultural Economics and Statistics Section, College of Agriculture, Nagpur (MS) \\ ${ }^{2}$ Associate Director of Research, Agriculture Research Station, Tal. Sindewahi Dist. Chandrapur (MS) \\ ${ }^{3} P G$ student, Agricultural Economics and Statistics Section, College of Agriculture, Nagpur (MS)
}

*Corresponding Author: -

\begin{abstract}
: -
The conventional paddy growing tracts are in worst crisis due to social, biological and technical setbacks. Well acclaimed rice bowls in several part of the nation is facing a decline in area, production and productivity. In India, there is a growing demand for rice due to ever escalating population. Rice is consumed both in urban and rural area and its consumption is growing due to high-income elasticity of demand. To meet the growing demand, a rapid income in paddy production is needed. But there is little scope to increase the area; hence increase in production and productivity with an improvement in efficiency of production to act as a technological breakthrough to meet the growing demand.
\end{abstract}

Keywords: - economic annalysis, traditional, sri method of paddy cultivation 


\section{INTRODUCTION}

The conventional paddy growing tracts are in worst crisis due to social, biological and technical setbacks. Well acclaimed rice bowls in several part of the nation is facing a decline in area, production and productivity. In India, there is a growing demand for rice due to ever escalating population. Rice is consumed both in urban and rural area and its consumption is growing due to high-income elasticity of demand. To meet the growing demand, a rapid income in paddy production is needed. But there is little scope to increase the area; hence increase in production and productivity with an improvement in efficiency of production to act as a technological breakthrough to meet the growing demand.

The System of Rice Intensification (SRI) is a method of paddy cultivation, though some consider and treat it as a technology. SRI is considered to be a disembodied technological breakthrough in paddy cultivation. SRI involves the application of certain management practices, which together provide better growing condition of rice plants, particulate in the root zone, than those for plants grown under traditional practice. This system seems to be promising to overcome shortage of water in irrigating rice. SRI was first introduced in Madagascar during the early 1980s by a French Missionary Priest, Father Henri de Laulanie, S.J.Since then SRI has been widely studied, researched and debated. SRI is a recent entry in to India. Formal experimentation of SRI in India was started in 2002-03 and Andhra Pradesh among the first state SRI has emerged as an important technology for rice production. SRI method totally deviates from the traditional way of cultivating irrigated paddy over centuries and hence it has differed any water saving capabilities. It in fact, challenges the received wisdom of paddy. SRI is environment- friendly. Reduced demand for water and frees up water for other users and soil that is not kept saturated has greater biodiversity. Un-flooded paddy fields do not produced methane, one of the major "greenhouse gasses" that are contributing towards global warming. The method uniqueness includes using less seeds, less water, less chemicals, etc. Paddy nursery is raised using 2 to $3 \mathrm{kgs}$ seed per acre of paddy as against the usual $30 \mathrm{kgs}$. Transplantation of the seedling is carried out fairly early, i.e., within 2 week after sowing as against 4-5 weeks. Transplanting is done in wide spaces of $20 \times 20$ or $25 \times 25$ centimeter with only one seedling per spot and hens the saving on seeds. The species transplanting allows for the spread of the plant with more number of tillers, i.e., between 50 and 100 as against 20 and 30 in the traditional case. SRI challenges assumptions and practices that have been in place for 100, even 1000 of years. Most rice farmer plant mature seedlings in clumps, fairly closely, with standing water maintained on the field for as a large part of the season as possible with the ideas of reducing the risk of crop failure.

Paddy is grown in Bhandara and Chandrapur district on large scale occupying major the area in the district. Paddy has, not only important place in internal market, but has its place in international market too. It has assumed a discernible significance with wider precepts and better potential. Hence, effort must be made for boosting the production of paddy in the country which has high potential for export. In view of growing demand for domestic consumption and export various agencies recognized the urgent need for increasing production in Bhandara and Chandrapur district. Paddy marketing is the performance of all business activities in the flow of paddy and milled rice from the point of initial production until they are in the hands of the ultimate consumers.

This study would help the farmers for earning money and increasing farm income from the cultivation of paddy crop which gives continuous higher income by maintaining irrigation facilities and financial facilities. Rice yields have been increasing since the 1960s, but since the 1990s, growth in rice production has been slower than population growth. Indeed, it is anticipated that rice production will need to increase by $30 \%$ by 2025 in order to sustain those who need it for sustenance.

The cultivation of paddy crop engages farmers, his family and lobour. It supply food stuff to his family and provide the better utilization of land, labour, and capital. In addition to this it reduces pressure on cereal as well as it gives a much higher return.

The study has undertaken according to tehsil, hence the researcher get idea about cost A, production, net return and marketing of paddy, at tehsil level as the study concerned with specific area (Bhandara and Chandrapur district). The application of the result will be useful only for the areas which has similar situation.

\section{Methodology}

The study was based on the input-output data obtained from sample farmers in Bhandara and Chandrapur districts. For selection of farmers, multi-stage sampling design was employed. In this procedure, at first stage, two major paddy growing districts following both traditional and SRI method of rice cultivation were purposively selected. From each district, two major paddy growing Talukas following both the methods of rice cultivation were selected at second stage. Then at third stage, three major paddy growing villages following traditional and SRI methods of rice cultivation were selected from each Talukas. In the final stage, ten farmers were randomly selected from each village comprising five farmers for SRI method and five farmers for traditional method of rice cultivation. Thus, the total sample size was 120. The necessary primary data was obtained from the sample farmer through personal interview with the help of pre-tested and well structured schedule. The data was collected certainly to the Kharif season of the agriculture year 2012-13. 
Table 1 Details of selected village wise farmers and their distribution

\begin{tabular}{|c|c|c|c|c|}
\hline Sr. No. & Name of District & Name of Talukas & Name of Villages & No. of farmers \\
\hline 1 & \multirow{6}{*}{ Bhandara } & \multirow{3}{*}{ Sakoli } & Virsi & 10 \\
\hline 2 & & & Sivnibandh & 10 \\
\hline 3 & & & Sangadi & 10 \\
\hline 4 & & \multirow{3}{*}{ Lakhandur } & pimpalgao & 10 \\
\hline 5 & & & madeghat & 10 \\
\hline 6 & & & Lakhandur & 10 \\
\hline 7 & \multirow{6}{*}{ Chandrapur } & \multirow{3}{*}{ Sindevahi } & Kanhalgaon & 10 \\
\hline 8 & & & Jatlapur tu. & 10 \\
\hline 9 & & & Sarkada & 10 \\
\hline 10 & & \multirow{3}{*}{ Mul } & Rajoli & 10 \\
\hline 11 & & & Mul & 10 \\
\hline \multirow[t]{2}{*}{12} & & & Chiroli & 10 \\
\hline & \multicolumn{3}{|c|}{ Total } & 120 \\
\hline
\end{tabular}

A list of farmers from the selected villages was obtained. For evaluating the present study, necessary primary data were obtained from the sample farmers through personal interview with the help of pre-tested and well-structured schedule. The data so collected pertained to the kharif season of the agricultural year 2012-13.

\section{Analytical Tools}

For the purpose of achieving the objective of the study. The collected data are subjected to the statistical analysis for this purpose, tabular and production function analysis will be employed.

The techniques of tabular presentation were used to assess the cost, returns and profits of the paddy crop in the study area. The percentage and averages were completed and camped to drown meaning full inferences.

The standard cost concept was used to study the economic analysis of paddy cultivation based on Dr. Sen's committee report (1979) given as fallows

Cost-A1: It includes the value of variable inputs

Cost-A2: Cost A1 + rent paid for leased in land, if any.

Cost-B1: Cost A1 + interest on value of owned fixed capital (other than land). Cost-B2: Cost-B1 + rental value of owned land + rent paid for leased in land. Cost-C1: Cost B1 + imputed value of family labour.

Cost-C2: Cost B2 + imputed value of family labour.

In the present study, the rent paid for leased in land was zero, as none of the sample farmers took land on lease basis. Hence, cost A1 and cost A2 are similar and are simply called as cost-A and only cost- C was estimated in the study and presented in the result.

\section{Production Function Analysis}

The Cobb-Douglas production function is the most widely used from of production functions for filling agricultural production data, because of its mathematical properties like case of interpretation and computational simplicity. In the present study Cobb-Douglas production function in the log form will be used as follows.

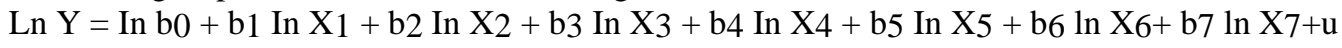

Where,

$\mathrm{Y}=$ Output (yield) quintal/ha.

$\mathrm{X} 1=$ Human labour (mandays/ ha).

$\mathrm{X}_{2}=$ Seeds $\mathrm{kg} / \mathrm{ha}$.

$\mathrm{X} 3=\mathrm{N} \mathrm{kg} / \mathrm{ha}$.

$\mathrm{X} 4=\mathrm{P} \mathrm{kg} / \mathrm{ha}$.

$\mathrm{X} 5$ = Farm yard manure in tonnes/ha.

X6 $=$ Expenditure on plant protection (Rs/ha).

$\mathrm{X} 7=$ Area under paddy cultivation (ha).

$\mathrm{Ln}=$ Normal log

$\mathrm{B}$ 0 to $\mathrm{b} 7=$ Coefficient

$\mathrm{U}=$ Error term

The above function was estimated by using OLS mathod assuming the error term (U) to be randomly and normaly distribution.

The above function was used for both the method of paddy cultivation. SRI and Traditional method, for identify the 
important factore affecting production of paddy under both methods. The estimates were further used for decomposition analysis.

\section{Decomposition analysis}

The output decomposition model as developed by Bisaliah (1977) was used for investigative. The contribution of various constituents' sources productivity difference between the SRI method and the traditional method rice cultivation for any two production functions. The total change in the productivity could be brought out by shifts in the production parameter. That defines the production function itself and by change in the input used levels. Therefore the production function will be considered as the convenient econometric tools for decomposing the productivity differences between two methods of cultivation.

In logarithm form, Cobb-Douglas production function for SRI method of paddy is;

LnYs $=\operatorname{lnbS} 0+$ bS $1 \operatorname{lnXS1}+$ bS2 $\operatorname{lnXS} 2+$ bS3 $\operatorname{lnXS} 3+$ bS4 $\operatorname{lnXS} 4+$ bS5 $\ln$ XS5 + bS6 $\operatorname{lnXS6}+$ bS7 lnXS7 + US--

Logarithm form of Cobb-Douglas production function for traditional method of paddy is;

$\ln \mathrm{YT}=\ln \mathrm{bT} 0+\mathrm{bT} 1 \ln \mathrm{XT} 1+\mathrm{bT} 2 \ln \mathrm{XT} 2+\mathrm{bT} 3 \ln \mathrm{XT} 3+\mathrm{bT} 4 \ln \mathrm{XT} 4+\mathrm{bT} 5 \ln \mathrm{XT} 5+\mathrm{bT} 6 \ln \mathrm{XT} 6+\mathrm{bT} 7 \ln \mathrm{XT} 7+\mathrm{UT}---$

Taking differences between (1) and (2) and adding some terms and subtracting the same terms.

$\mathrm{LnYS}-\ln \mathrm{YT}=(\ln \mathrm{bS} 0-\ln \mathrm{bT} 0)+(\mathrm{bS} 1 \operatorname{lnXS} 1-\mathrm{bT} 1 \operatorname{lnXT} 1+\mathrm{bS} 1 \ln \mathrm{XS} 1-\mathrm{bS} 1 \ln \mathrm{XS} 1)+(\mathrm{bS} 2 \operatorname{lnXS} 2-\mathrm{bT} 2 \operatorname{lnXT} 2+$ bS2 $\operatorname{lnXS} 2-\mathrm{bS} 2 \operatorname{lnXS} 2)+(\mathrm{bS} 3 \operatorname{lnXS} 3-\mathrm{bT} 3 \ln \mathrm{XT} 3+\mathrm{bS} 3 \operatorname{lnXS} 3-\mathrm{bS} 3 \operatorname{lnXS} 3)+(\mathrm{bS} 4 \operatorname{lnXs} 4-\mathrm{bT} 4 \operatorname{lnXT} 4+\mathrm{bS} 4$

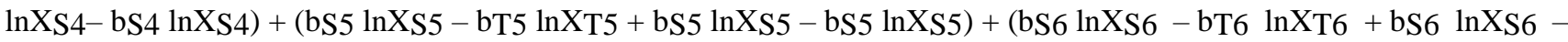
bS6 $\operatorname{lnXS6})+(\mathrm{bS} 7 \ln \mathrm{XS} 7-\mathrm{bT} 7 \ln \mathrm{XT} 7+\mathrm{bS} 7 \ln \mathrm{XS} 7-\mathrm{bS} 7 \ln \mathrm{XS} 7)+(\mathrm{U} 2-\mathrm{U} 1)$

By using logarithm rule equation (3) becomes;

$\ln (\mathrm{YS} / \mathrm{YT})=\{\ln [\mathrm{bS} 0 / \mathrm{bT} 0)\}+\{(\mathrm{bS} 1-\mathrm{bT} 1) \ln \mathrm{XS} 1+(\mathrm{bS} 2-\mathrm{bT} 2) \ln \mathrm{XS} 2+(\mathrm{bS} 3-\mathrm{bT} 3) \ln \mathrm{XS} 3+(\mathrm{bS} 4-\mathrm{bT} 4) \operatorname{lnXS} 4$

+ (bS5 - bT5) $\operatorname{lnXS} 5+(\mathrm{bS} 6-\mathrm{bT} 6) \ln \mathrm{XS} 6+(\mathrm{bS} 7-\mathrm{bT} 7) \ln \mathrm{XS} 7\}+\{\mathrm{bS} 1 \ln (\mathrm{XS} 1 / \mathrm{XT} 1)+\mathrm{bS} 2 \ln (\mathrm{XS} 2 / \mathrm{XT} 2)+\mathrm{bS} 3 \ln$

$(\mathrm{XS} 3 / \mathrm{XT} 3)+\mathrm{bS} 4 \ln (\mathrm{XS} 4 / \mathrm{XT} 4)+\mathrm{bS} 5 \ln (\mathrm{XS5} / \mathrm{XT5})+\mathrm{bS} 6 \ln (\mathrm{XS6} / \mathrm{XT} 6)\}+\mathrm{bS} 7 \ln (\mathrm{XS} 7 / \mathrm{XT} 7)\}+[(\mathrm{U} 2-\mathrm{U} 1)]$------- (4)

This is the decomposition model for decomposing the productivity difference between the SRI method and the traditional method of rice cultivation. This equation involves decomposing the logarithm of ratio of per hectare productivity of SRI and traditional method of rice cultivations. This is approximately a measure of percentage change in per hectare output between the SRI cultivation and traditional cultivation.

The summation of first and the second terms on the right hand side of the decomposition model together represented the productivity difference between the SRI method and traditional method, attributable to the difference in the cultural practices. The third term provided the productivity difference between the SRI cultivation and traditional cultivation attributable to the differences in the input use.

\section{Results And Discussion}

Size of holding of selected farmers

Size of holding indicates the area of land actually holding in different size of group. The Table 2 present per farm land utilization pattern of selected farmers.

Table 2 Size of holding of selected farmers

\begin{tabular}{|c|c|c|c|}
\hline Sr. No. & Particulars & Traditional (N=60) & SRI (N=60) \\
\hline \multirow{2}{*}{1} & Marginal (<1.0) & $\begin{array}{c}28 \\
(46.67) \\
(61.67)\end{array}$ \\
\hline 2 & Small (1.01-2.0) & 18 & 18 \\
& & $(30.00)$ & $(30.00)$ \\
\hline 3 & Medium (2.01-4.0) & 9 & $(8.33)$ \\
\hline & & $(15.00)$ & 0 \\
& Large (> 4.01) & $(8.33)$ & $(0.00)$ \\
\hline
\end{tabular}

(Figures in parentheses indicate percentage to the total sample)

It is revealed from the Table 2 that, the average size of holding for marginal, small, medium and large farmer were 46.67 per cent, 30.00 per cent, 15.00 per cent and 8.33 per cent in traditional method.

However, the average size of holding for marginal, small and medium farmer were 61.67 per cent, 30.00 per cent, 8.00 per cent, 8.33 per and zero per cent large size of holding in SRI method.

\section{Land utilization pattern of selected farmers}

Land utilization indicates the area of land actually utilized in different purpose like crop production, irrigated, un-irrigated, etc. The Table 3 present per farm land utilization pattern of selected farmers. 
It is revealed from Table 3 that, the average size of holding was 1.66 hectares in traditional method and 1.23 hectares in SRI method. However, the net cultivated area was 1.54 hectares and 1.17 hectares in traditional method and SRI method respectively. The percentage of cultivable land was more in case traditional method i.e. 92.77 per cent. While the proportion of area sown more than once was more in case of SRI method i.e. 36.58 per cent. The intensity of cropping was worked out 125.97 per cent in traditional method. The intensity of cropping is higher on SRI method 138.46 per cent because of more intensive use of land.

Table 3 Land utilization pattern of selected farmers

(Area in ha)

\begin{tabular}{|c|c|c|c|}
\hline \multirow{2}{*}{ Sr. No. } & Particulars & Traditional & SRI \\
& & & 1.23 \\
\hline 1 & Total land holding & 1.66 & $(100.00)$ \\
\hline 2 & Leased out & $(100.00)$ & 0.01 \\
& & 0.06 & $(0.81)$ \\
\hline 3 & Permanent fallow & $(3.61)$ & 0.17 \\
& & 0.04 & $(13.82)$ \\
\hline 4 & Current fallow & $(2.41)$ & 0.16 \\
& & 0.02 & $(13.01)$ \\
\hline 5 & Net cultivated area & $(1.21)$ & 0.89 \\
& & 1.54 & 0.45 \\
\hline 6 & Area sown more than once & $(92.77)$ & $(36.58)$ \\
\hline 7 & & 0.4 & 1.62 \\
\hline 8 & Gross crop area & $(24.09)$ & 182.02 \\
\hline
\end{tabular}

(Figures in parentheses indicate percentage to average size of holding)

\section{Nursery cost in Traditional and SRI methods of paddy production}

As there was difference in nursery management between traditional and SRI methods, resource use pattern and the expenditure made on the various inputs were analysed and the same are presented in Table 4.

Table 4 Nursery cost in Traditional and SRI methods of selected farmers

\begin{tabular}{|c|c|c|c|c|c|}
\hline \multirow{2}{*}{ Sr. No. } & Particulars & \multicolumn{2}{|c|}{ Traditional Method } & \multicolumn{2}{|c|}{ SRI Method } \\
\cline { 2 - 6 } & & Quantity & Value (Rs.) & Quantity & Value (Rs.) \\
\hline 1 & Seed (Kg.) & 48.23 & 1194.79 & 6.36 & 174.11 \\
& & & $(62.83)$ & & $(26.96)$ \\
\hline 2 & N (Kg.) & 6.58 & 85.86 & 4.07 & 53.04 \\
& & & $(4.51)$ & & $(8.21)$ \\
\hline 3 & Plant Protection & 57.78 & 189.16 & 11.92 & 29.79 \\
& Chemicals (gm.) & & $(9.95)$ & & $(4.61)$ \\
\hline 4 & Labour (mandays) & 2.82 & 431.62 & 2.46 & 388.88 \\
& & & $(22.71)$ & & $(60.22)$ \\
\hline
\end{tabular}

Note: 1) Figures in parentheses indicate percentage to the total

2) Area of nursery plot is 7.20 cents for traditional method and 4.62 cent for SRI method per hectare.

Traditional paddy farmers have used $48.23 \mathrm{~kg}$ of seed, $6.58 \mathrm{~kg}$ of fertilizer, $57.78 \mathrm{gm}$. of PPC and 2.82 mandays of human labour as against $6.36 \mathrm{~kg}$ of seed, $11.92 \mathrm{gm}$. of PPC and 2.6 mandays of human labour used by SRI paddy farmers.

The major expenditure item of nursery cost was expenditure made on seeds in traditional paddy (Rs. 1194.79) and SRI paddy (Rs. 174.11). The expenditure made on PPC (Rs.189.16) and labour (Rs.431.62) in traditional nursery management was higher than those in SRI nursery management (Rs.29.79 and Rs.388.88, respectively). The total nursery cost in traditional method (Rs.1901.67) was clearly higher than the total nursery cost in SRI method (Rs. 645.82). The share of seed was 62.83 per cent contributing largely to the higher total nursery cost in traditional method. In SRI method also the 
expenditure on seeds accounted to a share (26.96 per cent). In the traditional method, the share of fertilizer in total nursery cost was lowest 4.52 per cent and 8.21 per cent in SRI method, respectively. In the SRI method the share of PPC in total nursery cost was lowest 4.61 per cent and 9.95 per cent in traditional method.

\section{Per hectare cost of Cultivation in Traditional and SRI methods of paddy cultivation}

The profitability aspect of both the methods of paddy cultivation in the study area has been analysed by computing per hectare cost and returns. The pattern of inputs used in both the methods of paddy cultivation for sample farmers is depicted in Table 5 and 6. A glance at the table indicated that farmers of traditional paddy were found to use more of seeds (48.24 $\mathrm{kg}), \mathrm{N}$ nutrient $(90.12 \mathrm{~kg}), \mathrm{P}$ nutrient $(34.69 \mathrm{~kg})$ and $\mathrm{K}$ nutrient $(5.42 \mathrm{~kg})$ as against $6.36 \mathrm{~kg}$ of seeds, $84.10 \mathrm{~kg}$ of $\mathrm{N}$ nutrient, $30.74 \mathrm{~kg}$ of $\mathrm{P}$ nutrient and $4.10 \mathrm{~kg}$ of K nutrient by SRI paddy farmers. However, SRI paddy farmers used 143.55 mandays of human labour, 5.44 pair days of bullock labour, 24.70 hours of machine labour and 63.78 qt. of farm yard manure, which were more against 128.51 mandays of human labour, 6.56 pair days of bullock power, 28.83 hours of machine labour used by traditional paddy farmers. Irrigation charges, land revenue, depreciation and interest on fixed capital were found to be more for traditional paddy farmers, whereas interest on working capital, repairs, incidental and rental value of land was found to be more for SRI paddy farmers. The per hectare cost of cultivation (Rs. 54330.85) for SRI paddy was more when compared to that (Rs. 46671.10) of traditional paddy.

Table 5. Per hectare cost of cultivation for paddy crop (Traditional)

\begin{tabular}{|c|c|c|c|c|c|c|c|}
\hline SR. No. & $\begin{array}{llll}\mathbf{I} & \mathbf{T} & \mathbf{E} & \mathbf{M}\end{array}$ & & UNITS & $\begin{array}{l}\text { UNITS } \\
\text { Required }\end{array}$ & \begin{tabular}{|l} 
PRICE \\
PER UNIT
\end{tabular} & $\begin{array}{l}\text { COST IN } \\
\text { RS. }\end{array}$ & $\begin{array}{l}\text { PERCENT } \\
\text { TO TOTAL }\end{array}$ \\
\hline \multirow[t]{3}{*}{1} & \multirow[t]{3}{*}{ Hired Human Labour } & Male & Days & 16.83 & 182.10 & 3064.74 & 6.57 \\
\hline & & Female & Days & 87.68 & 106.31 & 9321.26 & 19.97 \\
\hline & & Total & Days & 104.51 & & 12386.00 & 26.54 \\
\hline \multirow[t]{3}{*}{2} & \multirow[t]{3}{*}{ Bullock Power } & Hired & Days & 3.10 & 249.60 & 773.76 & 1.66 \\
\hline & & Owned & Days & 3.46 & 249.60 & 863.62 & 1.85 \\
\hline & & Total & Days & 6.56 & & 1637.38 & 3.51 \\
\hline \multirow[t]{3}{*}{3} & \multirow[t]{3}{*}{ Machine } & Hired & Hrs. & 27.86 & 217.66 & 6064.01 & 12.99 \\
\hline & & Owned & Hrs. & 0.97 & 217.66 & 211.13 & 0.45 \\
\hline & & Total & Hrs. & 28.83 & & 6275.14 & 13.45 \\
\hline 4 & Seed & & Kg. & 48.24 & 24.77 & 1194.90 & 2.56 \\
\hline 5 & Manure & & Qt. & 41.20 & 65.82 & 2711.78 & 5.81 \\
\hline \multirow[t]{4}{*}{6} & \multirow[t]{4}{*}{ Fertilizer } & $\mathrm{N}$ & Kg. & 90.12 & 23.36 & 2105.20 & 4.51 \\
\hline & & $\mathrm{P}$ & Kg. & 34.69 & 26.71 & 926.57 & 1.99 \\
\hline & & $\mathrm{K}$ & Kg. & 5.42 & 27.54 & 149.27 & 0.32 \\
\hline & & Total & & 130.23 & & 3181.04 & 6.82 \\
\hline 7 & Irrigation & & Rs. & & & 456.99 & 0.98 \\
\hline 8 & Incidental & & Rs. & & & 37.09 & 0.08 \\
\hline 9 & Plant protection & & Rs & & & 1791.53 & 3.84 \\
\hline 10 & Repairs & & Rs. & & & 69.35 & 0.15 \\
\hline 11 & Working Capital & & Rs. & & & 29741.21 & 63.73 \\
\hline 12 & Depreciation & & Rs. & & & 185.60 & 0.40 \\
\hline 13 & Land Revenue & & Rs. & & & 79.40 & 0.17 \\
\hline 14 & Int. On Working Capital & & Rs. & & & 594.82 & 1.27 \\
\hline 15 & $\operatorname{cosT} " A "$ & & Rs. & & & 30601.03 & 65.57 \\
\hline 16 & Int. On Fixed Capital & & Rs. & & & 434.77 & 0.93 \\
\hline 17 & COST "B1" & & Rs. & & & 31035.80 & 66.50 \\
\hline 18 & Rental Value of Land & & Rs. & & & 11956.86 & 25.62 \\
\hline 19 & COST "B2" & & & & & 42992.66 & 92.12 \\
\hline \multirow[t]{3}{*}{20} & \multirow[t]{3}{*}{ Family Labour Charges } & Male & Days & 14.87 & 182.10 & 2707.82 & 5.80 \\
\hline & & Female & Days & 9.13 & 106.31 & 970.610 & 2.08 \\
\hline & & Total & Days & 24.00 & & 3678.437 & 7.88 \\
\hline 21 & CosT"C" & & Rs & & & 46671.10 & 100.00 \\
\hline \multirow[t]{2}{*}{22} & \multirow[t]{2}{*}{ Yield } & Main & Qt. & 42.91 & 1652.83 & 70922.94 & \\
\hline & & By & Qt. & 55.42 & 23.36 & 1294.611 & \\
\hline 23 & Value of Total Produce & & Rs & & & 72217.55 & \\
\hline 24 & Per Qt. Cost of Production & & & & & 1057.48 & \\
\hline
\end{tabular}

(Figures in parentheses indicate percentage to the Cost-C) 
Table 6. Per hectare cost of cultivation for paddy crop (SRI)

\begin{tabular}{|c|c|c|c|c|c|c|c|}
\hline SR. No. & $\begin{array}{llll}\mathbf{I} & \mathbf{T} & \mathbf{E} & \mathbf{M} \\
\end{array}$ & & UNITS & $\begin{array}{c}\text { UNITS } \\
\text { Required }\end{array}$ & $\begin{array}{c}\text { PRICE } \\
\text { PER UNIT }\end{array}$ & $\begin{array}{c}\text { COST IN } \\
\text { RS. }\end{array}$ & $\begin{array}{l}\text { PERCENT } \\
\text { TO TOTAL }\end{array}$ \\
\hline \multirow[t]{3}{*}{1} & \multirow[t]{3}{*}{ Hired Human Labour } & Male & Days & 24.70 & 183.04 & 4521.09 & 8.32 \\
\hline & & Female & Days & 88.92 & 107.44 & 9553.56 & 17.58 \\
\hline & & Total & Days & 113.62 & & 14074.65 & 25.91 \\
\hline \multirow[t]{3}{*}{2} & \multirow[t]{3}{*}{ Bullock Power } & Hired & Days & 2.46 & 234.60 & 577.12 & 1.06 \\
\hline & & Owned & Days & 2.98 & 234.60 & 699.11 & 1.29 \\
\hline & & Total & Days & 5.44 & & 1276.22 & 2.35 \\
\hline \multirow[t]{3}{*}{3} & \multirow[t]{3}{*}{ Machine } & Hired & Hrs. & 23.83 & 243.62 & 5805.46 & 10.69 \\
\hline & & Owned & Hrs. & 0.87 & 243.62 & 211.95 & 0.39 \\
\hline & & Total & Hrs. & 24.70 & & 6017.41 & 11.08 \\
\hline 4 & Seed & & $\mathrm{Kg}$. & 6.36 & 27.36 & 174.01 & 0.32 \\
\hline 5 & Manure & & Qt. & 63.78 & 70.00 & 4464.60 & 8.22 \\
\hline \multirow[t]{4}{*}{6} & \multirow[t]{4}{*}{ Fertilizer } & $\mathrm{N}$ & $\mathrm{Kg}$. & 84.10 & 23.50 & 1976.35 & 3.64 \\
\hline & & $\mathrm{P}$ & $\mathrm{Kg}$. & 30.74 & 36.45 & 1120.47 & 2.06 \\
\hline & & $\mathrm{K}$ & $\mathrm{Kg}$. & 4.10 & 34.25 & 140.43 & 0.26 \\
\hline & & Total & & 118.94 & & 3237.25 & 5.96 \\
\hline 7 & Irrigation & & Rs. & & & 310.52 & 0.57 \\
\hline 8 & Incidental & & Rs. & & & 48.12 & 0.09 \\
\hline 9 & Plant protection & & Rs & & & 1504.66 & 2.77 \\
\hline 10 & Repairs & & Rs. & & & 76.25 & 0.14 \\
\hline 11 & Working Capital & & Rs. & & & 31183.70 & 57.40 \\
\hline 12 & Depreciation & & Rs. & & & 171.27 & 0.32 \\
\hline 13 & Land Revenue & & Rs. & & & 61.30 & 0.11 \\
\hline 14 & Int. On Working Capital & & Rs. & & & 623.67 & 1.15 \\
\hline 15 & COST "A" & & Rs. & & & 32039.94 & 58.97 \\
\hline 16 & Int. On Fixed Capital & & Rs. & & & 434.77 & 0.80 \\
\hline 17 & COST "B1" & & Rs. & & & 32474.71 & 59.77 \\
\hline 18 & Rental Value of Land & & Rs. & & & 17297.05 & 31.84 \\
\hline 19 & COST "B2" & & & & & 49771.76 & 91.61 \\
\hline \multirow[t]{3}{*}{20} & \multirow[t]{3}{*}{ Family Labour Charges } & Male & Days & 17.77 & 183.04 & 3252.621 & 5.99 \\
\hline & & Female & Days & 12.16 & 107.44 & 1306.47 & 2.40 \\
\hline & & Total & Days & 29.93 & & 4559.09 & 8.39 \\
\hline 21 & COST"C"' & & Rs & & & 54330.85 & 100.00 \\
\hline \multirow{2}{*}{22} & \multirow[t]{2}{*}{ Yield } & Main & Qt. & 57.30 & 1784.00 & 102223.2 & \\
\hline & & By & Qt. & 72.85 & 26.45 & 1926.88 & \\
\hline 23 & Value of Total Produce & & Rs. & & & 104150.1 & \\
\hline 24 & Per Qt. Cost of Production & & & & & 914.55 & \\
\hline
\end{tabular}

(Figures in parentheses indicate percentage to the Cost-C)

The share of higher human labour in total cost was 26.54 per cent (Rs. 12386.00) for traditional paddy farmers and 25.91 per cent (Rs.14074.65) for SRI paddy farmers. The expenditure made on machine labour was 13.45 per cent and 11.08 per cent respectively for traditional paddy farmers and SRI paddy farmers. The next important item of expenditure in both the methods of paddy cultivation was the expenditure made on fertilizers, which worked out to be 6.82 per cent and 5.96 per cent, respectively for traditional and SRI paddy farmers. The rental value of land was the major expenditure contributing to the fixed cost (25.62 per cent and 31.84 per cent, respectively for traditional paddy farmers and SRI paddy farmers). The share of variable cost was 65.57 per cent (Rs. 30601.03) to the total cost in traditional paddy and 58.97 per cent (Rs. 
32039.94) in SRI paddy cultivation. The variable cost was found to be less by about Rs. 1438.91 in traditional method, when compared to that in SRI method. The per quintal cost of production was Rs. 1057.48 for traditional method and Rs. 914.55 for SRI method.

Table 7: Per hectare cost and returns from paddy cultivation

\begin{tabular}{|c|l|c|c|}
\hline Sr. No. & Items & Traditional method & SRI method \\
\hline I & Gross Return & 72217.55 \\
\hline I & Yield Qt./ha & 104150.08 \\
\hline A & Main produce & 42.91 & 57.30 \\
\hline B & By produce & 55.42 & 72.85 \\
\hline II & Price Rs/qt. & 1784.00 \\
\hline A & Main produce & 1652.83 & 26.45 \\
\hline B & By produce & 23.36 & 32039.94 \\
\hline 2 & Total Cost & 30601.03 & 49771.76 \\
\hline I & Cost A & 42992.66 & 54330.85 \\
\hline II & Cost B & 46671.10 & 72110.14 \\
\hline III & Cost C & 41616.51 & 54378.32 \\
\hline 3 & Net Return & 29224.89 & 49771.76 \\
\hline I & Cost A & 25546.45 & 3.25 \\
\hline II & Cost B & 2.36 & 1.92 \\
\hline III & Cost C & 1.68 \\
\hline I & Input - Output Ratio & 1.55 & \\
\hline I & Cost A &
\end{tabular}

The per hectare paddy output obtained in both the methods is presented in Table 2. The yield per hectare realized in traditional method was 42.91 quintals. The paddy yield realized by SRI paddy farmers was 57.30 quintals per hectare. There was a glaring difference between the two methods in the paddy straw yield. Traditional paddy farmers obtained 55.42 quintals per hectare and SRI paddy farmers realized 72.85 quintals per hectare.

The method-wise cost and return structure in paddy cultivation in study area is given in Table 7. The per hectare cost A, cost $\mathrm{B}$ and cost $\mathrm{C}$ for SRI method were more when compared to that in traditional method. For example, Cost $\mathrm{C}$ was more by about Rs.7659.75 for SRI when compared to that in traditional method. The per hectare gross returns realized for traditional paddy farmers and SRI paddy farmers, respectively were Rs. 104150.08 and Rs. 72217.55.

The net returns (returns over Cost C) were Rs. 25546.45 for traditional method and Rs. 49771.76 for SRI method. The returns per rupee spent were around Rs. 1.55 in traditional method and it was 1.92 in SRI method.

\section{Decomposition of input utilization for traditional method and SRI method of paddy crop}

The degree of management of the resources can be judged for the utilization of resources, the choice and the decision making. Beside this, it also indicates the level of technology adopted by the farmers. The farmers required to spend on various inputs like seed, manure, fertilizer, PPC, human labour and bullock labour. Therefore, it is necessary to know the pattern of expenditure on various inputs on per hectare basis.

Decomposition of inputs utilization in paddy production is presented in Table 8 . In traditional method per hectare human labour utilization was 128.51 human days, bullock power 6.56 days, machine labour $28.83 \mathrm{hrs,} \mathrm{seeds} \mathrm{was} 48.24 \mathrm{~kg}$, FYM $41.20 \mathrm{qt}$, PPC $1571.52 \mathrm{ml}$ and fertilizer $90.13 \mathrm{~kg} \mathrm{~N}, 34.69 \mathrm{~kg}$ P and $5.42 \mathrm{~kg} \mathrm{~K}$, respectively.

In SRI method per hectare human labour utilization was 143.55 human days, bullock labour 5.44 days, machine labour $24.70 \mathrm{hrs}$, seeds was $6.36 \mathrm{~kg}$, FYM $63.78 \mathrm{qtl}$, PPC $1446.79 \mathrm{ml}$ and fertilizer $84.10 \mathrm{~kg} \mathrm{~N}, 30.74 \mathrm{~kg}$ P and $4.10 \mathrm{~kg} \mathrm{~K}$, respectively.

Among the various sources responsible for total productivity difference. The different inputs contributing to the productivity difference between SRI method and traditional method. This implied that farmers growing SRI method paddy obtained higher output per hectare than that obtained by the farmers of traditional method of paddy by spending less on those inputs. On the other hand, FYM (22.58 qt/ha) and human labour (15.04 mandays/ha) contributed positively contributed whereas seed (-41.87 kg/ha), expenditure on PPC (-124.73 ml/ha) and fertilizer in N, P, K was (-6.02 kg/ha), ($3.95 \mathrm{~kg} / \mathrm{ha}),(-1.32 \mathrm{~kg} / \mathrm{ha})$ contributed negatively. 
Table 8: Decomposition of input utilization for traditional method and SRI method of paddy crop. (Per ha.)

\begin{tabular}{|c|c|c|c|c|c|}
\hline Sr No. & Particulars & Unit & Traditional & SRI & Difference (S-T) \\
\hline 1 & Seeds & Kg. & 48.24 & 6.36 & -41.87 \\
\hline 2 & Human labour & Mandays & 128.51 & 143.55 & 15.04 \\
\hline 3 & Nitrogen (N) & Kg. & 90.13 & 84.10 & -6.02 \\
\hline 4 & Phosphorus (P) & Kg. & 34.69 & 30.74 & -3.95 \\
\hline 5 & Potassium( K) & Kg. & 5.42 & 4.10 & -1.32 \\
\hline 6 & Farm Yard Manure (FYM) & Qt. & 41.20 & 63.78 & 22.58 \\
\hline 7 & Plant Protection Chemicals (PPC) & Ml & 1571.52 & 1446.79 & -124.73 \\
\hline 8 & Yield & Qt./ha & & & \multicolumn{2}{|c|}{14.39} \\
\hline I & Main produce & & 42.91 & 57.30 & 17.43 \\
\hline II & By produce & & 55.42 & 72.85 & \\
\hline
\end{tabular}

The decomposition analysis revealed that the per hectare yield of traditional method of paddy was less than that in SRI method. The productivity difference between main produce in the SRI paddy and traditional paddy was estimated to be $14.39 \mathrm{~kg} / \mathrm{ha}$ and by produce was $17.43 \mathrm{~kg} / \mathrm{ha}$ respectively

\section{Cobb-Douglas production function estimate for SRI and traditional methods of paddy cultivation}

One of the major objectives of the study was to identify the important factors affecting production of paddy under traditional and SRI methods of paddy cultivation. For this purpose, the popularly used Cobb-Douglas production function was fitted. The production parameters of the estimated Cobb-Douglas production function are presented in Table 9

Table 9. Cobb-Douglas production function estimate for SRI and traditional methods of paddy cultivation

\begin{tabular}{|c|c|c|}
\hline Particulars & SRI & Traditional \\
\hline Intercept & 2.841 & 4.569 \\
\hline Human labour & $\begin{array}{l}0.139 * \\
(0.060)\end{array}$ & $\begin{array}{l}-0.194 \\
(0.166)\end{array}$ \\
\hline Seeds & $\begin{array}{l}0.108 * \\
(0.064)\end{array}$ & $\begin{array}{l}-0.002 \\
(0.006)\end{array}$ \\
\hline Nitrogen $(\mathrm{N})$ & $\begin{array}{l}0.042 * * \\
(0.015)\end{array}$ & $\begin{array}{l}0.040 * \\
(0.047)\end{array}$ \\
\hline Phosphorus (P) & $\begin{array}{l}0.005 * * \\
(0.002)\end{array}$ & $\begin{array}{l}-0.001 \\
(0.005)\end{array}$ \\
\hline Farm Yard Manure (FYM) & $\begin{array}{l}-0.002 \\
(0.001)\end{array}$ & $\begin{array}{l}0.001 * \\
(0.002)\end{array}$ \\
\hline Plant Protection Chemicals (PPC) & $\begin{array}{l}0.021 * \\
(0.009)\end{array}$ & $\begin{array}{l}-0.012 \\
(0.024)\end{array}$ \\
\hline Area under crop & $\begin{array}{l}-0.035 \\
(0.023)\end{array}$ & $\begin{array}{l}-0.016 \\
(0.024)\end{array}$ \\
\hline $\mathrm{R}^{2}$ & $0.651 *$ & 0.115 \\
\hline$\sum \mathrm{bi}$ & 0.174 & 0.274 \\
\hline Deviation from unity & 0.826 & 0.726 \\
\hline $\mathrm{F}-$ Value & 13.86 & 0.973 \\
\hline $\begin{array}{l}\text { Return to scale indicate by test Of } \\
\text { significance }\end{array}$ & Decreasing & Decreasing \\
\hline
\end{tabular}

Note:1)* and $* *$ indicate significance at 5 per cent and 1 per cent levels, respectively.

2) Figure within the parenthesis are standard errors.

The coefficient of multiple determinations $\left(\mathrm{R}^{2}\right)$ was 0.115 for estimated production function of traditional method and it was 0.651 for SRI method. 
The return to scale imply the behaviour of the change of total return when all the inputs are changed simultaneously in the same proportion and is indicated by the sum of the regression coefficient in our estimated Cobb-Douglas production function. Return to scale are increasing, constant or diminishing accordingly as the sum of regression coefficients is greater than, equal to, or less than unity. The sum of regression coefficient were found to 0.274 and 0.174 in case of traditional and SRI method of paddy cultivation.

In order to see whether or not return to scale were constant, the sum of regression coefficient tested for their division from unity it was observed that 0.274 and 0.174 was not significantly different from unity and thus indicated decreasing return to scale in case of traditional and SRI method of paddy cultivation

In case of traditional and SRI method of paddy cultivation it was found that return to scale was decreasing. The $\mathrm{F}-\mathrm{value}$ was noticed in traditional method and SRI method was 0.973 and 13.86 , respectively.

In traditional method, nitrogen and FYM positively significant and seed rate, human labour, phosphorus, PPC and area was negatively significant. The elasticity coefficients in the case of SRI method indicated that the paddy output was significantly and positively influenced by all resources except FYM and area.

Coefficient of decomposition analysis beetween SRI and traditional methods of paddy cultivation

Using the decomposition analysis, the productivity difference between the SRI paddy and traditional paddy (yield gap) was decomposed into its constituent sources and the results are presented in Table 10.

Among the various sources responsible for total productivity difference. The different inputs contributing to the productivity difference between SRI method and traditional method were FYM (0.001), seed (0.007) and nitrogen (0.047) contributed positively whereas human labour (-0.074), expenditure on PPC (-0.002), phosphorus (-0.001) contributed negatively. The return to scale was -0.088 . The contribution of coefficient of $\left(\mathrm{R}^{2}\right)$ to the productivity difference between SRI and traditional methods due to was 0.291 .

Table 10. Coefficient of decomposition analysis beetween SRI and traditional methods of paddy cultivation

\begin{tabular}{|c|c|c|}
\hline Particulars & Coefficients & Standard Error \\
\hline Intercept & 0.280 & \\
\hline Human labour & -0.074 & 0.113 \\
\hline Seeds & 0.007 & 0.006 \\
\hline Nitrogen (N) & 0.047 & 0.030 \\
\hline Phosphorus (P) & 0.001 & 0.004 \\
\hline Farm Yard Manure (FYM) & 0.001 & 0.002 \\
\hline Plant Protection Chemicals (PPC) & -0.002 & 0.0167 \\
\hline Area under crop & -0.066 & 0.022 \\
\hline R2 & $0.291 *$ & \\
\hline Ebi & -0.088 & \\
\hline F - Value & 3.060 & \\
\hline
\end{tabular}

Note: * indicate significance at 5 per cent levels.

\section{Adoption levels and constraints in SRI method of paddy cultivation}

Adoption levels of sample farmers in following suggested practices of SRI method are presented in table 11. Complete application of suggested practice is considered as complete adoption level and any deviation from the suggested practice is considered as partial adoption level. Nursery area 2.5 cents for 1 ha paddy cultivation: majority 58.33 per cent of the sample farmers adopted partially nursery area and

41.67 per cent of farmers adopted it suggested nursery area. Seed rate 5kg/ha: Among the sample farmers

33.33 percent of them applied the suggested seed rate whereas the remaining 66.67 per cent of them used different levels of seed rate.

Transplanting 8-12 days aged seedlings: The sample farmers constituting 60.00 per cent to the total followed the suggested transplanting time of seedlings whereas the remaining 40.00 percent of them did not follow the suggested transplanting time. 
Table 11 Adoption levels in SRI method of paddy cultivation $\mathrm{N}=60$

\begin{tabular}{|c|c|c|c|}
\hline Sr. No. & Suggested Practices in SRI Method & \multicolumn{2}{|c|}{ Adoption Level } \\
\cline { 3 - 4 } & & Complete & Partial \\
\hline 1 & Nursery area 2.5 cents (for 1ha) & 25 & 35 \\
& & $(41.67)$ & $(58.33)$ \\
\hline 2 & Seed rates 5 kg/ha & 20 & 40 \\
& & $(33.33)$ & $(66.67)$ \\
\hline 3 & Transplanting 8-12 days aged seedlings & 36 & 24 \\
& & $(60.00)$ & $(40.00)$ \\
\hline 4 & Careful transplanting of soil and roots & 43 & 17 \\
& & $(71.67)$ & $(28.33)$ \\
\hline 5 & Wide spacing (25x25 cm ${ }^{2}$ or 30x30 cm $\left.{ }^{2}\right)$ & 46 & 14 \\
& & $(76.67)$ & $(23.33)$ \\
\hline 6 & Weed management & 38 & 22 \\
& & $(63.33)$ & $(36.67)$ \\
\hline 7 & Water management & $(23.33)$ & $(76.67)$ \\
\hline 8 & & 17 & 43 \\
& & $(28.33)$ & $(71.67)$ \\
\hline
\end{tabular}

(Figures in parentheses indicate percent to total number of farmers)

Careful transplanting of seedlings soil and roots intacted: majority of the sample farmers $(71.67 \%)$ followed suggested transplanting method whereas, 28.33 percent of the sample farmers did not follow the suggested transplanting method.

Wider spacing $\left(25 \times 25 \mathrm{~cm}^{2}\right.$ or $\left.30 \times 30 \mathrm{~cm}^{2}\right)$ : majority of the sample farmers $(81.66 \%)$ followed suggested transplanting method whereas, $18.34 \%$ of the sample farmers did not follow the suggested transplanting method. Weed management: Of the total sample farmers 63.33 per cent of them followed the suggested weed management practice where as 36.67 per cent of the sample farmers did not practice the suggested weed management. Water management: Nearly 76.67 per cent of the sample farmers did not follow the suggested water management practice where as 23.33 per cent of the sample farmers completely adopted the suggested water management practice. Organic manure application (10 t/ha): Of the total sample farmers 28.33 per cent of them applied suggested organic manure where as 71.66 per cent of the sample farmers did not apply the suggested quantity of organic manure.

Reasons for practicing SRI method of paddy cultivation

The details reasons for practicing SRI method of paddy cultivation of selected farmers are presented in Table 12.

Table 12 Reasons for practicing SRI method of paddy cultivation

\begin{tabular}{|c|c|c|c|}
\hline Sr. No. & Particulars & Frequency & Rank \\
\hline 1 & Higher yield and less seed rate & 60 & I \\
\hline 2 & Less water requirement & 58 & II \\
\hline 3 & Less fertilizer requirement & 56 & III \\
\hline 4 & Less incidence of pest and diseases & 55 & IV \\
\hline 5 & Less cost & 49 & V \\
\hline
\end{tabular}

Almost the farmers growing SRI method of paddy expressed that higher yield and less seed rate was the major reason for following SRI method of paddy. So, this criterion was placed in the first rank among all the reasons for adopting the SRI method. Less water requirement was the second major reason for practicing the SRI method by the sample farmers. The saving in water was one of the major reasons which attracted the sample farmers to adopt the SRI method. Saving in fertilizer requirement was observed in SRI method of paddy cultivation. Farmers expressed that less fertilizer requirement was one of the reason to adopt the SRI method. Majority of the sample farmers expressed that less incidence of pest and diseases was the fourth most important reason for practicing SRI method. Less cost was considerably less and sixth rank in SRI method. Less cost requirement was one of the reasons to adopt the SRI method.

Constraints in practicing SRI method of paddy cultivation

The details Constraints in practicing SRI method of paddy cultivation of selected farmers are presented in Table 13. 
Table 13 Constraints in practicing SRI method of paddy cultivation

\begin{tabular}{|c|c|c|c|}
\hline Sr. No. & Particulars & Frequency & Rank \\
\hline 1 & Labour requirement is more & 56 & I \\
\hline 2 & Weed manage & 52 & II \\
\hline 3 & Required skilled labour & 50 & III \\
\hline 4 & High rainfall & 47 & IV \\
\hline 5 & Unavailability of specific implements & 46 & V \\
\hline 6 & Higher seedling mortality & 40 & VI \\
\hline
\end{tabular}

High labour requirement was the major constraint in practicing SRI method. Especially during transplanting and weeding days sample farmers faced the dearth of labour availability. The SRI method was a labour intensive method of paddy cultivation. The next major constraint in SRI method was high weed infestation. Skillful labour third major constraint in SRI method. The specific constraint pertaining to the study area was poor drainage condition especially during heavy rainy seasons. The other constraints expressed by the sample farmers were manual conoweeder operation and high seedling mortality.

\section{Conclusions:}

From the present study the following conclusion are drawn:-

The major expenditure item of nursery cost was expenditure made on seeds in traditional paddy (Rs. 1194.79) and SRI paddy (Rs. 174.11). The expenditure made on PPC (Rs. 189.16) and labour (Rs. 431.62) in traditional nursery management was higher than those in SRI nursery management (Rs.29.79 and Rs.388.88, respectively). In the traditional method, the share of fertilizer in total nursery cost was lowest 4.52 per cent and 8.21 per cent in SRI method, respectively. Per hectare cost of cultivation of traditional method farmers at cost 'A', cost 'B' and cost 'C' were Rs. 30601.03, Rs. 42992.66 and Rs. 46671.10 respectively. The per hectare cost of cultivation SRI method farmers at cost 'A', cost 'B' and cost 'C' were Rs. 32039.94, Rs. 49771.76 and Rs. 54330.85 respectively. The Per quintal Cost of production of traditional method paddy growers was Rs. 1057.48. It was higher in SRI method paddy growers i.e. Rs. 914.55.The highest net return obtained from the SRI method i.e. Rs 49771.76 followed by traditional method i.e. Rs. 25546.45. The return per rupee spent was around Rs. 1.92 for SRI paddy method and Rs.

1.55 for traditional paddy method. The productivity difference between yield of main produce in the SRI paddy and traditional paddy was estimated to be $14.39 \mathrm{~kg}$ and yield of by produce was $17.43 \mathrm{~kg}$ respectively. The sum of regression coefficient was found to 0.274 and 0.174 in case of traditional and SRI method of paddy cultivation. However, decreasing returns to scale were noticed in both traditional paddy and SRI paddy production. Complete adoption level was high in the case of wider spacing (81.66 per cent) farmers followed by careful transplanting of soil and roots intacted seedlings practice ( 81.66 per cent) farmers, weed management (63.33 per cent) farmers and transplanting time (60.00 per cent) farmers. Partial adoption level was high in the case of water management (76.67 per cent) farmers followed by organic manure application (71.66 per cent) farmers and seed rate (66.67 per cent) farmers. Major reasons for practicing SRI method by sample farmers were higher yield levels and less seed rate. Major constraints in practicing SRI method were labour requirement is more, weed menace and required skilled labour.

\section{References}

[1].Barah B.C. (2009). Economic and Ecological benefits of system of rice intencification (SRI) in Tamil Nadu. Agricultural Economics Research Review, 22: 209-214.

[2].Barah, B.C. and S. Pandey, 2005. Rainfed rice production systems in Eastern India: An on farm diagnosis and policy alternatives. Indian Journal of Agricultural Economics, 60(1): 110-136.

[3].Barret, C. B., C. M. Moser, O. Mhugh, and J. Bavison, 2003. Better technology, better plots or better farmers and quest: Identifying changes in productivity and risk among Malagasy rice farmers. American Journal of Agricultural Economics, 86(4): 869-888.

[4].Basavaraja H., S.B. Mahajanashetti and P.Shivanagaraju.(2008). Technological change in paddy production: A comparative analysis of traditional and SRI method of cultivation' Indian Journal of Agril. Economics, 63(4).:629-640.

[5].Bisaliah, S. 1977, decomposition analysis of output change under new production technology in wheat farming: Some implications to returns on investment. Indian Journal of Agricultural Economics, 32(3): 193-201.

[6].Gupta, D. D., A. Rathi, and K. K. Shama, 1985. Economics of paddy cultivation in Haryana. Agriculture Situation in India, 42: 1051-1058.

[7].Halder Surjit, Honnaiah and G.Govindaraj, 2012. System of Rice Intensification (SRI) method of rice cultivation in West Bangal (India): An Economic analysis.Paper prepared for presentation at the International Association Of Agricultural Economics (IAAE) Triennial conference, Foz do Iquacu, Brazil, 18-24 Agust,2012.

[8].Kaul Sushila, Ghasi Ram and Sanjeev Pawar, 2009. Economics analysis of productivity and profitability in Rice production in India. Agril situation in India.pp-3. 